\title{
Analysis of Positioning at Kasih Ibu Hospital Surakarta
}

Muhamad Marwan Dhani*

* Correspondent Author: marwan.dhani@gmail.com

* Kasih Ibu Hospital, J1. Brigjend Slamet Riyadi No.404, Purwosari, Surakarta City, Central Java 57142, Indonesia

\begin{tabular}{l}
\hline I N D E X I N G \\
\hline Keywords: \\
Positioning; \\
Hospital; \\
Service Quality;
\end{tabular}
\begin{abstract}
A B S T R AC T
Kasih Ibu Hospital is one of the private B type hospitals in Surakarta residency which is facing a tight competition in maintaining its quality in proportion to its income. Kasih Ibu Hospital competes with other type B hospitals, namely X Surakarta Hospital and Y Hospital Surakarta. This research used a descriptive method. The population was the service users of Kasih Ibu Hospital, X Hospital Surakarta and Y Hospital Surakarta. A sample of 50 people was taken by accidental sampling. Data collection was by questionnaire. Data analysis was performed by Multidimensional Scaling (MDS) and biplot perception maps. X Hospital Surakarta is the closest competitor of Kasih Ibu Hospital Surakarta, with Euclidean distance of 2.8127. X Surakarta Hospital, more prominent intangibles, and empathy dimensions. Kasih Ibu Hospital Surakarta is more prominent in the dimensions of responsiveness, and at a lower level is the reliability and assurance dimension. Y Hospital Surakarta does not specifically stand out on the dimension of service quality based on patient perception. The dimensions which although not too prominent but the closest are empathy. X Surakarta Hospital is the closest competitor of Kasih Ibu Hospital Surakarta. X Hospital Surakarta, more prominent intangibles and empathy dimensions. Kasih Ibu Hospital Surakarta is more prominent in the dimensions of responsiveness, and at the lower level is the reliability and assurance dimension.
\end{abstract}

Kata kunci:

Positioning;

Rumah Sakit;

Kualitas Pelayanan;

\begin{abstract}
Rumah Sakit Kasih Ibu merupakan salah satu rumah sakit swasta tipe B di karesidenan Surakarta yang tengah menghadapi kompetisi ketat dalam mempertahankan kualitasnya agar sebanding dengan pendapatannya. Rumah Sakit Kasih Ibu bersaing dengan rumah sakit tipe B lainnya, yaitu RS X Surakarta dan RS Y Kandang Sapi Surakarta. Penelitian ini menggunakan metode deskriptif. Populasi adalah pengguna jasa pelayanan RS Kasih Ibu, RS X Surakarta, dan RS Y Surakarta. Sampel sejumlah 50 orang diambil dengan accidental sampling. Pengumpulan data dengan kuesioner. Analisis data dilakukan dengan Multidimentional Scaling (MDS) dan peta pesepsi biplot. RS X Surakarta merupakan pesaing terdekat RS Kasih Ibu Surakarta, dengan jarak euclidean sebesar 2,8127. RS X Surakarta, lebih menonjol dalam dimensi tangibles dan emphaty. RS Kasih Ibu Surakarta lebih menonjol pada dimensi responsiveness, dan pada tingkat yang lebih rendah adalah dimensi reliability dan assurance. Adapun RS Y Surakarta tidak secara spesifik menonjol satu dimensi kualitas pelayanan berdasarkan persepsi pasien. Dimensi yang walaupun tidak terlalu menonjol tetapi paling dekat adalah emphaty. RS X Surakarta merupakan pesaing terdekat RS Kasih Ibu Surakarta. RS X Surakarta, lebih menonjol dalam dimensi tangibles dan emphaty. RS Kasih Ibu Surakarta lebih menonjol pada dimensi responsiveness, dan pada tingkat yang lebih rendah adalah dimensi reliability dan assurance.
\end{abstract}

(C) 2018 JMMR. All rights reserved

Article history: Received 2018-Aug-03; Revised 2018-Aug-29; Accepted 2018-Dec-12

\section{INTRODUCTION}

Hospital is an organization that is very complex because it is capital intensive, labor intensive, technology intensive and also problematic. Hospital is a place of health promotion, prevention and healing of disease, health improvement and recovery of patients conducted in multidisciplinary by various groups of educated and trained professionals concerning disciplines of medicine, law, economics, social, and management. Circumstances that illustrate that hospital is a complex and multi-functional organization above cause social function of hospital to be more dominant $\frac{1}{\text {. }}$.

Hospital as organization that provides health services also faces the era of globalization and environmental change, especially health care environment, so there is a need to address challenges that hospital management has. A more advanced and developing environment includes health and medical technologies that continue to change. There is also a paradigm shift in the field of health. Government begins to deregulate and privatize health sector. Government begins to provide convenience to private 
sector to build hospitals, so that there is a possibility of "competition" between hospitals 2 .

Competition of hospital industry also occurs in Surakarta. Surakarta until 2016 has a total of 13 hospitals. Kasih Ibu Hospital Surakarta is one of the private B type hospitals in Surakarta residency which is facing a tight competition in maintaining its quality in proportion to its income. Hospitals in the Surakarta Residency area that has similar type with Kasih Ibu Hospital are two hospitals, namely X Hospital Surakarta and Y Hospital Surakarta.

In an era of increasingly fierce competition, improving service quality and measurement is one of the important issues to develop business efficiency and growth ${ }^{-}$. Identity of the hospital that is built can be in the form of service dimensions that are seeded as a distinctive feature of the service from Kasih Ibu Hospital. Regarding to the development of the identity, it is necessary to create a perceptual mapping to position the patient's perception of the service dimension, compared to the competitor's hospital. Perceptual mapping is a graphical technique used by researchers who try to visualize respondent perceptions, usually in two dimensions that are a combination of rankings on several factors ${ }^{4}$. Based on this, it is necessary to conduct research on the positioning of Kasih Ibu Hospital based on the perception of the community of health service users.

\section{RESEARCH METHOD}

This research used descriptive method, which is a research method carried out with the main objective to objectively describe a situation. Descriptive research method is used to solve or answer problems that are being faced in the current situation ${ }^{5}$. The sampling technique used was accidental sampling, which is also called convenience sampling, namely selection of samples from anyone who happens to exist or found according to the wishes of researchers. Data collection in this study was conducted by using questionnaires. The researcher used questionnaires to obtain information about thoughts, feelings, attitudes, beliefs, values, perceptions, personality, and behavior of respondents. The researcher attempts to measure various characteristics by using questionnaires - . Positioning of each hospital was known by using Multidimentional Scaling (MDS) analysis which is then depicted with biplot map of perception to know the position of the hospital respectively based on consumer perception on the services of each hospital.

\section{RESULT AND DISCUSSION}

The characteristics of respondents examined in this study can be described as follows:

Table 1. Characteristics of the Respondents

\begin{tabular}{|c|c|c|c|}
\hline NO & CHARACTERISTIC & FREQUENCY & $(\%)$ \\
\hline \multirow[t]{7}{*}{1} & Age & & \\
\hline & $\leq 30$ years old & 4 & 8,0 \\
\hline & 31 - 40 years old & 12 & 24,0 \\
\hline & $41-50$ years old & 24 & 48,0 \\
\hline & $51-60$ years old & 8 & 16,0 \\
\hline & $>60$ years old & 2 & 4,0 \\
\hline & Total & 50 & 100,0 \\
\hline \multirow[t]{4}{*}{2} & Gender & & \\
\hline & Man & 22 & 44,0 \\
\hline & Woman & 28 & 56,0 \\
\hline & Total & 50 & 100,0 \\
\hline \multirow[t]{6}{*}{3} & Education & & \\
\hline & SD & 2 & 4,0 \\
\hline & SMP & 14 & 28,0 \\
\hline & SMA & 21 & 42,0 \\
\hline & University & 13 & 26,0 \\
\hline & Total & 50 & 100,0 \\
\hline \multirow[t]{6}{*}{4} & Monthly Income & & \\
\hline & $<$ Rp. $1.000 .000,00$ & 17 & 34,0 \\
\hline & $\begin{array}{l}\text { Rp. } 1.000 .000,00-R p . \\
2.500 .000,00\end{array}$ & 16 & 32,0 \\
\hline & $\begin{array}{l}\text { Rp. } 2.500 .000,00-\text { Rp. } \\
5.000 .000,00\end{array}$ & 13 & 26,0 \\
\hline & $>$ Rp. $5.000 .000,00$ & 4 & 8,0 \\
\hline & Total & 50 & 100,0 \\
\hline \multirow[t]{7}{*}{5} & Job & & \\
\hline & Employees & 12 & 24,0 \\
\hline & Public Servant & 10 & 20,0 \\
\hline & Entrepreneur & 10 & 20,0 \\
\hline & Farmer & 5 & 10,0 \\
\hline & Others & 13 & 26,0 \\
\hline & Total & 50 & 100,0 \\
\hline
\end{tabular}

The table above shows that based on age, most respondents aged 41-50 years, namely 24 respondents $(48.0 \%)$, and at least those aged $>60$ years, namely 2 respondents $(4.0 \%)$. Based on gender, the majority of respondents were women, namely 28 respondents $(56.0 \%)$. Based on education, most respondents had high school education, namely 21 respondents $(42.0 \%)$, and at least those with elementary education, 2 respondents $(4.0 \%)$. Based on monthly income, the majority of respondents earn $<\mathrm{Rp}$. $1,000.0000 .00$, which is 17 respondents $(32.0 \%)$, and at least those with income $>$ Rp. 5,000,000.00, which is 4 respondents $(8.0 \%)$. Based on work, most of the respondents were others, namely 13 respondents $(26.0 \%)$, and at least those who had jobs as farmers, namely 5 respondents $(4.0 \%)$. 


\section{Perception Description of the Hospital Services Quality}

Perception of hospital service quality in this study was interpreted by referring to the grand mean value of service quality for each dimension. The interpretation of the quality of hospital services was done by making class intervals with the number of 5 classes in the score range 1 to 4 . Each class interval was then interpreted with qualitative sentences. The class intervals and interpretations are as follows:

$1.00-1.60=$ Very Not Good

$1,61-2,20=$ Not Good

$2.21-2.80=$ Medium

$2.81-3.40=$ Good

$3.41-4.00=$ Very Good

Consumer perceptions of hospital service quality can be described as follows:

\section{Perception Description of the Hospital Services Quality} in Tangibles Dimension

Based on the results of the study, it can be described the perception of the hospital services quality in tangibles dimension as follows:

Table 2. Perception Description of the Hospital Services Quality in Tangibles Dimension

\begin{tabular}{llll}
\hline No. & \multicolumn{1}{c}{ Hospital } & $\begin{array}{c}\text { Grand } \\
\text { Mean }\end{array}$ & Category \\
\hline 1. & Hospital of Kasih Ibu & 3,10 & Good \\
2. & Hospital of X & 3,27 & Good \\
& & & \\
3. & Hospital of $\mathrm{Y}$ & 3,18 & Good \\
\hline
\end{tabular}

The table above shows that consumer perceptions of the hospital services quality in tangibles dimensions are good in all hospitals.

\section{Perception Description of the Hospital Services Quality} in Reliability Dimension

Based on the results of the study, it can be described the perception of hospital service quality in reliability dimensions as follows:

The table above shows that consumer perceptions of hospital service quality are of good reliability in all hospitals.
Table 3. Perceptions Description of the Hospital Services Quality in Reliability Dimension

\begin{tabular}{llll}
\hline No. & Hospital & $\begin{array}{l}\text { Grand } \\
\text { Mean }\end{array}$ & Category \\
\hline 1. & Hospital of Kasih Ibu & 3,16 & Good \\
2. & Hospital of X & 3,18 & Good \\
3. & Hospital of Y & 3,06 & Good \\
\hline
\end{tabular}

Perception Description of the Hospital Services Quality in Responsiveness Dimension

Based on the results of the study, it can be described the perception of the Hospital Services Quality in Responsiveness Dimension as follows:

Table 4. Perceptions Description of the Hospital Services Quality in Responsiveness Dimension

\begin{tabular}{llll}
\hline No. & Hospital & $\begin{array}{l}\text { Grand } \\
\text { Mean }\end{array}$ & Category \\
\hline 1. & Hospital of Kasih Ibu & 3,18 & Good \\
2. & Hospital of X & 3,07 & Good \\
3. & Hospital of Y & 3,02 & Good \\
\hline
\end{tabular}

The table above shows that consumer perceptions of the Hospital Services Quality in Responsiveness Dimension are good in all hospitals.

Perception Description of the Hospital Services Quality in Assurance Dimension

Based on the results of the study, it can be described the perception of the Hospital Services Quality in Assurance Dimension as follows:

Table 5. Perception Description of the Hospital Services Quality in Assurance Dimension

\begin{tabular}{llll}
\hline No. & Hospital & $\begin{array}{l}\text { Grand } \\
\text { Mean }\end{array}$ & Category \\
\hline 1. & Hospital of Kasih Ibu & 3,12 & Good \\
2. & Hospital of X & 3,10 & Good \\
3. & Hospital of Y & 3,05 & Good \\
\hline
\end{tabular}

The table above shows that consumer perceptions of the hospital services quality in assurance dimensions are good in all hospitals. 
Description of Perceptions of the Hospital Services Quality in Empathy Dimension

Based on the results of the study, it can be described the perception of the Hospital Services Quality in Empathy Dimension as follows:

Table 6. Description of Perceptions of the Hospital Services Quality in Empathy Dimension

\begin{tabular}{llll}
\hline No. & Hospital & $\begin{array}{l}\text { Grand } \\
\text { Mean }\end{array}$ & Category \\
\hline 1. & Hospital of Kasih Ibu & 2,94 & Good \\
2. & Hospital of X & 3,07 & Good \\
3. & Hospital of Y & 3,15 & Good \\
\hline
\end{tabular}

The table above shows that consumer perceptions of the hospital services quality in empathy dimensions are good in all hospitals.

\section{The Positioning in Kasih Ibu Hospital of Surakarta Based on Public Perception of Health Service User}

At the initial stage of positioning in Kasih Ibu Hospital, a competitor's analysis was conducted. This analysis is important so that Kasih Ibu Hospital can identify the closest competitor, and then can identify the weakness and strength of the hospital compared to its competitors. The main competitor of Kasih Ibu Hospital is the same hospital in category B, namely $\mathrm{X}$ Hospital and $\mathrm{Y}$ Hospital determination of the closest competitor in this study was done by looking at euclidean distance (euclidean distance). Smaller euclidean distance indicates closer competition. Euclidean distance is calculated by looking at the coordinate mapping value using multidimensional scale (MDS). How good multidimensional scale (MDS) mapping seen from the Stress value is. Result of data analysis got value of Stress Kruskall equal to 0,00000 or $0,00 \%$. Based on the stress value, it can be concluded that MDS mapping is in the perfect category.

Based on the results of MDS analysis obtained the coordinates of each hospital as follows

Table 7. Hospital Coordinates in MDS Mapping

\begin{tabular}{llll}
\hline \multirow{2}{*}{ No. } & \multirow{2}{*}{ Hospital } & \multicolumn{2}{l}{ Coordinate } \\
\cline { 3 - 4 } & & $\mathbf{X}$ & Y \\
\hline 1. & Kasih Ibu Hospital & $-0,757$ & $-2,404$ \\
2. & X Hospital & $-2,117$ & 0,058 \\
3. & Y Hospital & $-1,918$ & 1,393 \\
\hline
\end{tabular}

Based on the coordinates of MDS mapping above, the euclidean distance can be calculated. The formulas used are as follows:

Distance Euclidean $==\sqrt{(\mathrm{Xz}-\mathrm{Xi})^{2}+(\mathrm{Yz}-\mathrm{Yi})^{2}}$

Where $\mathrm{Xz}$ and $\mathrm{Yz}$ are the coordinates of Kasih Ibu Hospital and $\mathrm{Xi}$ and $\mathrm{Yi}$ are the coordinates of competing hospitals. The calculation of euclidean distance can be described in the table as follows:

Table 8. Euclidean Distance and The Closest Competitor Ranking

\begin{tabular}{lllllll}
\hline $\begin{array}{l}\text { Hospital } \\
\text { Competito } \\
\text { rs }\end{array}$ & $\begin{array}{l}\text { Kasih } \\
\text { Hospital }\end{array}$ & \multicolumn{3}{l}{$\begin{array}{l}\text { Hospital } \\
\text { Competitors }\end{array}$} & $\begin{array}{l}\text { Euclidea } \\
\text { n } \\
\text { Distance }\end{array}$ & $\begin{array}{l}\text { Ran } \\
\text { k. }\end{array}$ \\
\cline { 2 - 5 } & $\mathbf{X z}$ & $\mathbf{Y z}$ & $\mathbf{X i}$ & $\mathbf{Y i}$ & & \\
\hline PKU Muh. & - & - & - & 0,05 & 2,8127 & 1 \\
Hospital & 0,75 & 2,40 & 2,11 & 8 & & \\
& 7 & 4 & 7 & & & \\
Y Hospital & - & - & - & 1,39 & 3,9705 & 2 \\
& 0,75 & 2,40 & 1,91 & 3 & & \\
& 7 & 4 & 8 & & & \\
\hline
\end{tabular}

The table shows that X Hospital Surakarta is the closest competitor of Kasih Ibu Hospital Surakarta. This is seen from a smaller euclidean distance.

Furthermore, to see the dimensions of service quality that are being positioning each hospital, mapping is done using biplot. The results are as follows:

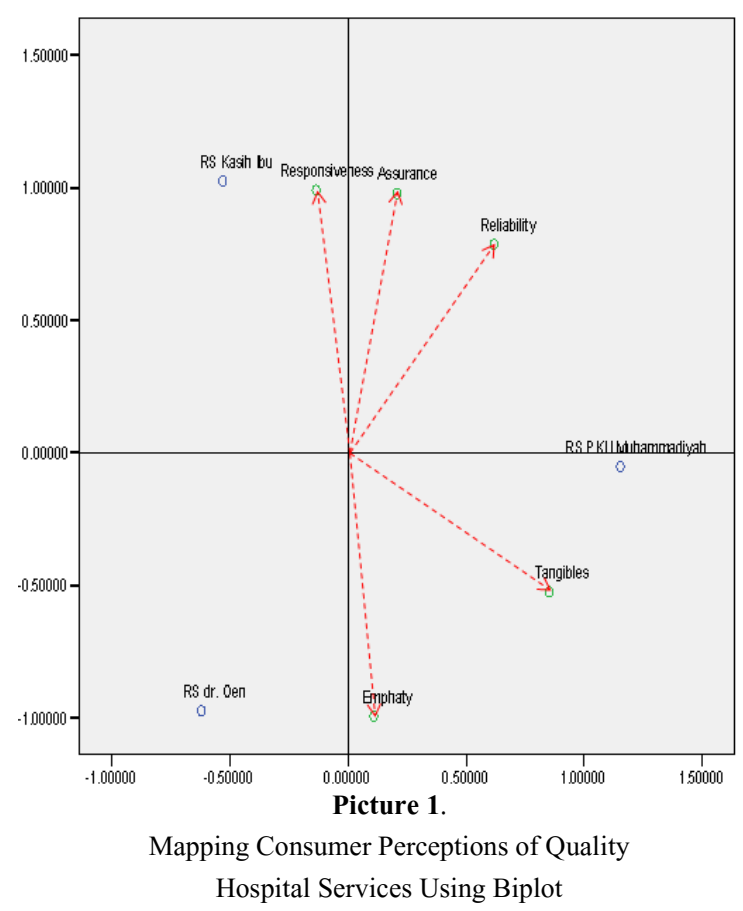


Perceptual map is a useful tool where brands currently available for market segments can be visualized ${ }^{\text {? }}$. The picture above shows that X Hospital Surakarta is the main competitor of Kasih Ibu Hospital Surakarta. X Hospital Surakarta is more prominent in tangibles and empathy dimensions. Kasih Ibu Hospital Surakarta is more prominent in the dimensions of responsiveness, and at a lower level in the reliability and assurance dimensions.

\section{RESULT AND DISCUSSION}

According to the law of the Republic of Indonesia Number 44 of 2009 concerning Hospitals, states that a hospital is a health service institution that organizes individual health services in a comprehensive manner that provides inpatient, outpatient and emergency services. Based on the Regulation of the Minister of Health of the Republic of Indonesia Number 129 / Menkes / SK / II / 2008, hospitals are health facilities that provide individual health services including promotive, preventive, curative and rehabilitative services that provide inpatient, outpatient, and emergency services.

Service quality is the evaluation of the extent to which service providers can meet customer expectations ${ }^{8}$.The results showed that the positioning of Kasih Hospital in Surakarta was based on consumers' perceptions of service, having the main competitor of X Hospital Surakarta. X Hospital Surakarta, more prominent in tangibles and empathy dimensions. Kasih Ibu Hospital Surakarta is more prominent in the dimensions of responsiveness, and at a lower level in the reliability and assurance dimension. The Y hospital Surakarta does not specifically stand out one dimension of service quality based on patient perception. The dimensions which although not too prominent but the closest is empathy.

Explicit or implicit the reference framework of Positioning strategies is competition (positioning based on competitors) ${ }^{9}$. When looking at the results of the research above, it is seen that Kasih Ibu Hospital implemented a strategy to face its closest competitors, X Hospital Surakarta by implementing a strategy to prioritize responsiveness, reliability, and assurance. This is because Kasih Ibu Hospital responds positively in facing X Hospital Surakarta which has relative superiority in infrastructure and physical form. Infrastructure includes real features of service delivery, relating to equipment, furniture, physical appearance of the hospital, facilities, availability of resources, and environment ${ }^{10}$.

The strategy of Kasih Ibu Hospital by creating excellence and increasing the responsiveness, reliability, and assurance dimension of the service, will be perceived positively by the consumers. Services carried out will be accepted and felt by consumers who come to service. the process of communicating with our target market through the use of product marketing mix variables, prices, distribution channels, and the attractiveness of certain promotions, in such a way that helps consumers differentiate products from competitors and understand how certain products satisfy their needs ${ }^{11}$. If consumers have a positive interpretation of the dimensions of responsiveness, reliability, and assurance services, then consumers' perceptions will be positive, so this affects their behavior in performing services at Kasih Ibu Surakarta Hospital.

The description above is in accordance with the theories of the Department of Education which states that in the process of perception, there are three main components:

1. Selection is the process of filtering the senses against external stimuli, the intensity and type can be many or few $\stackrel{12}{ }$.

2. Interpretation, namely the process of organizing information so that it has a meaning for someone. Interpretation is influenced by various factors, such as past experience, the system of values adopted, motivation, personality, and intelligence. Interpretation also depends on one's ability to organize complex information categoryzation into a scholar.

3. Interpretation and perception are then translated in the form of behavior as a reaction.

Perception plays an important role in the concept of positioning because humans interpret a product through perception ${ }^{13}$. Service quality is the evaluation of the extent to which service providers can meet customer expectations ${ }^{14}$. Perception is the experience of objects, behavior or relationships obtained by inferring information and interpreting messages $\frac{15}{}$. Consumer perceptions of service in the dimensions of responsiveness, reliability, and assurance enhanced as positioning strategy of Kasih Ibu Hospital Surakarta will underlie the service interpretation of Kasih Ibu Hospital. Interpretation of consumers will form an image of Kasih Ibu Hospital as a hospital that is responsive, reliable (reliability) and there is assurance of security (assurance). Positive image will have an impact on changes in consumer attitudes and behavior in carrying out product purchases, because consumers tend to avoid using products that have a negative image ${ }^{16}$. The focus is on how the staff interact with patients or customers; physical environment where services are provided; system used for customer transactions such as centralized scheduling, online 
registration, or bill payments; or a typical service delivery model 17 .

Positioning is the act of designing an offer and the company's image to occupy a distinctive place in the mind of the target market ${ }^{18}$. Positioning of Kasih Ibu Hospital Kasih Surakarta based on consumer perception on service, has the main competitor X Surakarta Hospital. X Hospital Surakarta is more prominent in tangibles, which has the meaning of external appearance of physical facilities, equipment, personnel and communication ${ }^{19}$, and empathy dimensions. Kasih Ibu Hospital Surakarta is more prominent in responsiveness dimension, which is the willingness to help customers and perform services quickly 20 , and at a lower level in the reliability and assurance dimension. Then Y Hospital Surakarta does not specifically stand out one dimension of service quality based on patient perception.

\section{CONCLUSION}

The positioning of Kasih Ibu Hospital Surakarta based on consumer perception about service has the main competitor of X Hospital Surakarta. X Hospital Surakarta more stands out in the dimensions of tangibles and empathy. Kasih Ibu Hospital Surakarta more stands out in the dimensions of responsiveness and to a lesser extent the dimensions of reliability and assurance. Y Hospital Surakarta does not specifically stand out one dimension of service quality based on patient perception. The dimensions which although not too prominent but the closest are empathy.

\section{REFERENCE}

1. Hasan, S. (2015). Strategi Rumah Sakit dalam Menghadapi Krisis Public Relations Menurut Perspektif Fiqh Muamalat. Jurnal An-Nisbah, 2(1), Oktober 2015, 479-403.

2. Ristrini. (2005). Perubahan Paradigma Jasa Pelayanan Kesehatan Rumah Sakit dan Rekomendasi Kebijakan Strategis Bagi Pimpinan. Jurnal Manajemen Pelayanan Kesehatan (JMPK), 8(1), Maret 2005, 3-9.

3. Chakraborty, R., \& Majumdar, A. (2011). Measuring Consumer Satisfaction In Health Care Sector: The Applicability of Servqual. Journal of Arts, Science \& Commerce. II(4), Oct. 2011, 149-160

4. Tezar, M., Rohayati, Y., \& Aurachman, R. (2016). Analisis Positioning Program Pascasarjana Magister Manajemen (MM) Telkom University Berdasarkan Perceptual Mapping dengan Metode Multidimensional
Scaling. Proceeding of Engineering, 3(2), Agustus 2016, 2914-2920.

5. Notoatmodjo, S. (2010). Metodologi Penelitian Kesehatan. Jakarta: Rineka Cipta.

6. Johnson, B \& Christensen, L. (2012). Educational Research Quantitative, Qualitative, and Mixed Approaches. Osaka: Sage Publication, Inc.

7. Stone, M. A., \& Desmond, J. (2007). Fundamentals of Marketing. New York: Routledge.

8. Ahmed, R. \& Samreen, H. (2011). Assessing The Service Quality of Some Selected Hospitals In Karachi Based On The Servqual Model. Pakistan Business Review. July 2011, 266-314.

9. Peter, J.P., Olson, J.C. (2010). Consumer Behavior and Marketing Strategy. New York: The McGraw-Hill Companies, Inc.

10. Azizan, N. A., \& Mohamed, B. (2013). The Effects Of Perceived Service Quality On Patient Satisfaction At A Public Hospital In State Of Pahang, Malaysia. Asian Journal of Social Sciences \& Humanitie, 2(3), August 2013, 307-323.

11. Kardes, F. R., Cronley, M. L., Cline, T. W. (2011). Consumer Behavior. Mason, Ohio: South-Western Cengage Learning.

12. Solomon, M., Bamossy, G., Askegaard, S., \& Hogg, M. K. (2006). Consumer Behaviour: A European Perspective. London: Prentice-Hall, Inc.

13. Mu'ti Hanif, Abdul. (2008). Positioning Radio Kota Perak 94, 6 FM Yogyakarta dalam Meraih Iklan dan Pendengar. Skripsi thesis, UIN Sunan Kalijaga Yogyakarta.

14. Naik, J. R. K., Anand, B., \& Bashir, I. (2013). Healthcare Service Quality and word of mouth: Key drivers to achieve Patient Satisfaction. Pacific Business Review International, 5(12), June 2003, 3944.

15. Rakhmat, J. (2007). Psikologi Komunikasi. Bandung : PT. Remaja Rosdakarya.

16. Irfan, S.M., Ijaz, A., and Farooq, M.M. (2012). Patient Satisfaction and Service Quality of Public Hospitals in Pakistan: An Empirical Assessment. Middle-East Journal of Scientific Research. Vol. 12 Issue 6, page 870-877.

17. Gershon, H. J. (2003). Strategic Positioning: Where Does Your Organization Stand?. Journal of Healthcare Management, 48(1), January/February 2003, 12-14. 
18. Kotler, P., \& Keller, K. L. (2012), Marketing Management, Global Edition 14e, London: Pearson Education Limited 2012

19. Tjiptono, F dan Chandra, G. (2011). Service, Quality \& Satisfaction. Yogyakarta: Andi Offset.
20. Zeithaml, V. A., Parasuraman, A, Berry, L. L. (1990). Delivering Quality Service: Balancing Customer Perception and Expectation. New York: The Free Press: A Divission of Macmillan, Inc. 